\title{
Lanea carlsi conodont apparatus reconstruction and its significance for subdivision of the Lochkovian
}

\author{
Ladislav Slavík \\ Acta Palaeontologica Polonica 56 (2), 2011: 313-327 doi: http://dx.doi.org/10.4202/app.2009.0046
}

A cosmopolitan spathognathodontid taxon "Ancyrodelloides carlsi" is not regarded in this paper as one of the earliest known representatives of Ancyrodelloides according to former concepts, but is considered as conspicuous member of the genus Lanea. The taxon shows distinct morphological innovation of the upper surface of the Pa element within the Lanea lineage which makes it easily recognizable worldwide and suitable for global correlation. Presented stratigraphic correlation using conodonts and other faunal groups qualifies a short-lived Lanea carlsi as probably the best marker of the middle Lochkovian base. This paper presents reconstruction of the apparatus of $L$. carlsi which is the first complete reconstruction in the genus Lanea. The comparison of the Lanea apparatus and assumed apparatus of early Ancyrodelloides from the Požáry Quarries (Barrandian, Czech Republic) resulted to proposal of an alternative concept of evolution of these two genera. The relatively short-lived genus Ancyrodelloides is considered to split off from the Lanea clade in the late middle Lochkovian by the entry of Ancncyrodelloides transitans.

Key words: Conodonta, apparatus reconstruction, biostratigraphy, Lochkovian, Barrandian, Prague Synform.

Ladislav Slavík [slavik@gli.cas.cz], Laboratory of Paleobiology and Paleoecology, Institute of Geology AS CR, v.v.i., Rozvojová 269, CZ-165 02 Praha 6, Czech Republic.

This is an open-access article distributed under the terms of the Creative Commons Attribution License (for details please see creativecommons.org), which permits unrestricted use, distribution, and reproduction in any medium, provided the original author and source are credited. 
FoF Full text $(496.5 \mathrm{kB})$ 